\title{
Dental Caries and Associated Factors Among Patients Attending the University of Gondar Comprehensive Hospital Dental Clinic, North West Ethiopia: A Hospital-Based Cross-Sectional Study
}

\section{Amare Teshome \\ Getaneh Andualem (D) \\ Kirubel Derese}

Department of Dentistry, University of Gondar, Gondar, Ethiopia
This article was published in the following Dove Press journal: Clinical, Cosmetic and Investigational Dentistry

Purpose: Dental caries are an emerging public health problem in developing countries in the last two decades. However, there is a paucity of data on dental caries in northwest Ethiopia. This study investigated the prevalence of dental caries and associated factors in northwest Ethiopia.

Patients and Methods: A hospital-based cross-sectional study was conducted in 368 patients who visited the University of Gondar Comprehensive Hospital Dental Clinic. A systematic random sampling technique was used to select the samples. Data were collected by three qualified dental surgeons using a pre-designed questionnaire modified from a WHO oral health survey and the clinical examination was done using the WHO dental caries diagnosis guideline. Data analysis was done using SPSS 20. Descriptive data were presented in tables and logistic regression analysis was done to identify the possible predisposing factors using odds ratios with $95 \%$ confidence interval.

Results: The prevalence of dental caries in this study was $23.64 \%$ (95\% CI: $19.30,28.00)$ with a significant difference between females (30.56\%) and males (17.02\%). Being female $(\mathrm{AOR}=2.15$ (95\% CI: 1.31, 3.52), poor oral hygiene practice $(\mathrm{AOR}=2.44$ (95\% CI: 1.46 , 4.07), being diabetic ( $\mathrm{AOR}=8.15$ (95\% CI: 3.2, 20.75), low educational level $(\mathrm{AOR}=1.81$ (95\% CI: 1.05, 3.1), low monthly income (AOR=3.05 (95\% CI: 1.54, 6.02) and halitosis $(A O R=10.98$ (95\% CI: 5.68, 2.24) were significantly associated with dental caries. The mean DMFT score was $1.095 \pm 0.24$ (SD). The majority of the DMFT $(70.59 \%)$ was due to decay, while filled tooth accounted for only $2.17 \%$ of the DMFT. The DMFT score was higher in females (0.625), urban residents $(0.85)$, and those with montly income of $\leq 2500$ Ethiopian birr (0.86). The mean DMFT was 0.13 .

Conclusion: The prevalence of dental caries in the study participants was $23.64 \%$ andwas higher in males than females and in diabetic patients. Female gender, poor tooth brushing habits, diabetes mellitus, and halitosis were significant predictors associated with dental caries.

Keywords: dental caries, tooth decay, DMFT, predisposing factors, oral hygiene practice

\section{Background}

Dental caries is a bacterial infectious disease of the hard tissue of the tooth by the interaction of cariogenic bacteria and easily fermentable carbohydrates. ${ }^{1}$ Dental caries is one of the major orofacial problem and indicator of the burden of oral 
health throughout the globe. ${ }^{2,3}$ Even if, the prevalence of dental caries varies from country to country, it is a fact that the disease has a wide geographic distribution, high prevalence, and graded severity. ${ }^{2,4}$ The prevalence was higher in minority and economically poor community. ${ }^{5}$

Dental caries affects the quality of life of the affected patients and highly affect the economy of the individual and society. The presence of carious tooth affects work performance, eating and speaking and also impair the growth and development. ${ }^{6,7}$

In the last two decades, the prevalence of dental caries has declined in developed countries, ${ }^{8}$ while it showed a dramatic increase in the developing countries due to unaffordability of the dental services, and unavailability of dental clinics in rural settings. ${ }^{9}$ A national survey done in Malawi showed $49.0 \%$ of 35-44 years adults had dental caries and the prevalence becomes $49.2 \%$ in 65-74 years. Moreover, the mean DMFT was raised as age increases from 12 years $(\mathrm{DMFT}=0.67)$ to 65-74 years $(\mathrm{DMFT}=6.87) .{ }^{10}$ A study done in Eritrea showed $78 \%$ of the participants had dental caries and the prevalence of dental caries in Ethiopia was ranged from 36.3\%-78.2\%. ${ }^{11,12}$ Another study conducted in Turkey revealed females were 1.83 times at risk of developing dental caries. ${ }^{13}$ Lower socioeconomic status has a significant effect on the occurrence of dental caries in adults. ${ }^{11}$

The emerging of increased consumption of fermentable carbohydrates, low level of awareness about oral health, poor tooth brushing habits, and scarcity of dental centers are the possible factors for the increased prevalence of dental caries in developing countries. ${ }^{14,15}$ Moreover, change in way of life, eating habits, and sociodemographic factors also increase the prevalence of dental caries. $^{7,13,16,17}$

To date, there is a paucity of data on the prevalence and associated factors of dental caries in the study area. Due to this, the present study aimed to determine the prevalence of dental caries and associated factors in patients who visited the dental clinic of the University of Gondar specialized hospital.

\section{Patients and Methods}

\section{Setting}

This cross-sectional study was done at the University of Gondar comprehensive Hospital dental clinic from September 1, 2019-December 31, 2019. University of Gondar specialized hospital provides health care services over 5 million people and it's located $750 \mathrm{~km}$ from Addis
Ababa, the capital city of Ethiopia. The dental clinic is one of the Specialty clinics in the hospital that provides inpatient and outpatient dental health services for the population in the area.

\section{Study Participants}

All populations in the catchment area were the source population for the study and those who were 6 and above and visited the dental clinic of the University of Gondar would be included in the study. Patients with 6 and above years were examined for dental caries. All patients who visited the dental clinic within the study period and signed the consent form were included and examined for the presence of dental caries.

\section{Exclusion Criteria}

- Critically ill patients

- A patient with a dental emergency

- Patients refused to sign the consent

\section{Sampling Technique and Procedure}

A sample size of 368 participants was selected using the single population proportion formula

$$
N=\frac{Z^{2} p(1-p)}{d^{2}}
$$

With the following assumptions; The prevalence of dental caries $(\mathrm{P})$ to be $78.2 \%$ as estimated in Debre tabor hospital, Ethiopia, ${ }^{11}$ confidence level (CI) of 95\%, marginal error $(\mathrm{d}=5)$, and non-response rate of $10 \%$.

\section{Sampling Procedure}

Systematic random sampling would be used $(k=4)$. The first participant was selected by a simple random method.

\section{Data Collection}

A structured questionnaire, modified from WHO oral health survey $2013,{ }^{18}$ was prepared and a face to face interview was conducted in the dental clinic. The interview questionnaire was developed in English, translated into the local language of Amharic, and back into English. Two dental professionals reviewed the questionnaire for its clearness, sensitivity to culture, and the presence of appropriate words to the community. A pilot study was done in 40 patients before the administration of data collection. The data collected were socio-demographic characteristics, tooth brushing habits, dietary habits, and other medical conditions. The PI trained the data collectors for 2 days 
on how to approach, interview, maintaining confidentiality, and research ethics. A day to day supervision was made by the PI to check the completeness of the questionnaires.

\section{Intra-Oral Examination}

The intra-oral examination was done according to the WHO oral health survey guideline ${ }^{18}$ using dental probes, dental mirrors, and tissue forceps. A patient was considered to be carious if a lesion in a pit or fissure or on the smooth tooth surface had a detectable softened floor, or undermined enamel. A Tooth was considered to be missing because of caries if a person gave a history of pain and/or the presence of the cavity before extraction. The severity or experience of dental caries was evaluated by using the mean DMFT (permanent tooth) and dmft (primary dentition). The dentist did an intra-oral dental $x$-ray when it was indicated.

\section{Data Analysis}

Each questionnaire was checked for completeness before fed into a computer. The study variables were coded and entered into Epi-Info version 7 and transferred to SPSS version 20 for analysis. Descriptive statistics were computed. The association between the independent variables and dental caries was initially investigated using bivariate analysis and those with a p-value of $\leq 0.25$ were included in the multivariable analysis. Results were presented using OR with its 95\% CI.

\section{Ethical Consideration}

Ethical approval was sought from the University of Gondar ethical review board (IRB) before the commencement of the study. Besides, a study permit was acquired from the University of Gondar Department of Dentistry. Written consent was obtained from the participants, and written assent was taken from parents or legal guardians for under 18 years. All patients with pain were managed as an emergency during their visit to the dental clinic.

\section{Results}

Socio-demographic characteristics of the participants

The mean age of the study participants was $30 \pm 14.766$ SD years and $1 / 3$ rd of the participants were within the age group of 20-29 years (37.2\%). Out of 368 participants, 180 (48.9\%) were females. The majority of the study participants were orthodox (89.7\%), and from urban residents (78.8\%).

More than $2 / 3$ rd of the participants (73.6\%) had a monthly income of $\leq 2500$ Ethiopian birr and $77.4 \%$ of the participants had formal education (Table 1).

Oral hygiene practice of the participants
Table I Socio-Demographic Characteristics of the Patients Attended University of Gondar Comprehensive Hospital Dental Clinic $(n=368)$

\begin{tabular}{|c|c|c|c|}
\hline \multicolumn{2}{|l|}{ Variable } & \multirow{2}{*}{$\begin{array}{l}\text { Number } \\
68 \\
137 \\
92 \\
26 \\
45\end{array}$} & \multirow{2}{*}{$\begin{array}{l}\text { Percent } \\
18.5 \\
37.2 \\
25.0 \\
7.1 \\
12.2\end{array}$} \\
\hline Age (years) & $\begin{array}{l}<20 \\
20-29 \\
30-39 \\
40-49 \\
\geq 50\end{array}$ & & \\
\hline Gender & $\begin{array}{l}\text { Male } \\
\text { Female }\end{array}$ & $\begin{array}{l}188 \\
180\end{array}$ & $\begin{array}{l}51.1 \\
48.9\end{array}$ \\
\hline Marital status & $\begin{array}{l}\text { Single } \\
\text { Married } \\
\text { Divorced }\end{array}$ & $\begin{array}{l}169 \\
184 \\
15\end{array}$ & $\begin{array}{l}45.9 \\
50.0 \\
4.1\end{array}$ \\
\hline Occupation & $\begin{array}{l}\text { Farmer } \\
\text { Student } \\
\text { Governmental employee } \\
\text { NGO-employee } \\
\text { Merchant/Personal } \\
\text { business }\end{array}$ & $\begin{array}{l}54 \\
128 \\
68 \\
9 \\
109\end{array}$ & $\begin{array}{l}14.7 \\
34.8 \\
18.5 \\
2.4 \\
29.6\end{array}$ \\
\hline Religion & $\begin{array}{l}\text { Orthodox } \\
\text { Muslim } \\
\text { Protestant } \\
\text { Catholic }\end{array}$ & $\begin{array}{l}330 \\
23 \\
8 \\
7\end{array}$ & $\begin{array}{l}89.7 \\
6.3 \\
2.2 \\
1.9\end{array}$ \\
\hline Residency & $\begin{array}{l}\text { Urban } \\
\text { Rural }\end{array}$ & $\begin{array}{l}290 \\
78\end{array}$ & $\begin{array}{l}78.8 \\
21.2\end{array}$ \\
\hline Monthly income & $\begin{array}{l}\leq 2500 \text { ETB } \\
>2500 \text { ETB }\end{array}$ & $\begin{array}{l}271 \\
97\end{array}$ & $\begin{array}{l}73.6 \\
26.4\end{array}$ \\
\hline $\begin{array}{l}\text { Educational } \\
\text { status }\end{array}$ & $\begin{array}{l}\text { Has no Formal education } \\
\text { Has formal education }\end{array}$ & $\begin{array}{l}83 \\
285\end{array}$ & $\begin{array}{l}22.6 \\
77.4\end{array}$ \\
\hline
\end{tabular}

More than 2/3rd (73.1\%) of the participants had tooth brushing habit and of them, $31.0 \%$ had no fixed time to brush their teeth. Only $7.5 \%$ of the participants brushed their teeth twice/day. A traditional tooth brushing stick ("Mefakia") (48.7\%\%) and a toothbrush with paste $(49.8 \%)$ were the commonly used materials by the participants (Table 2).

Dietary habits, Smoking habits, and other systemic diseases

The majority of the study participants $(74.2 \%)$ had consumed fermentable carbohydrates. Hot drinks (Tea and coffee) and soft beverages were commonly used carbohydrates by the participants (Table 3 ).

Twenty-three (8.4\%) participants were smokers, 5.9\% were diabetic patients (DM) and 3\% were hypertensive patients (Table 3). 
Table 2 Oral Hygiene Habits and Practice of the Participants (Self-Reported)

\begin{tabular}{|c|c|c|c|}
\hline \multicolumn{2}{|c|}{ The Habit of Tooth Brushing } & \multirow{2}{*}{$\begin{array}{l}\text { Number } \\
269 \\
99\end{array}$} & \multirow{2}{*}{$\begin{array}{l}\text { Percentage } \\
73.1 \\
26.9\end{array}$} \\
\hline Toothbrush & $\begin{array}{l}\text { Yes } \\
\text { No }\end{array}$ & & \\
\hline $\begin{array}{l}\text { Frequency of } \\
\text { tooth brushing }\end{array}$ & $\begin{array}{l}\geq 3 \text { times/day } \\
\text { Twice/day } \\
\text { Once/day } \\
\text { Irregularly }\end{array}$ & $\begin{array}{l}4 \\
20 \\
76 \\
169\end{array}$ & $\begin{array}{l}1.5 \\
7.4 \\
28.3 \\
62.8\end{array}$ \\
\hline $\begin{array}{l}\text { Time of tooth } \\
\text { brushing }\end{array}$ & $\begin{array}{l}\text { Before bed } \\
\text { Morning } \\
\text { Both in the morning } \\
\text { and before bed } \\
\text { No fixed time }\end{array}$ & $\begin{array}{l}11 \\
117 \\
27 \\
114\end{array}$ & $\begin{array}{l}4.1 \\
43.5 \\
10.0 \\
42.4\end{array}$ \\
\hline $\begin{array}{l}\text { Material for } \\
\text { tooth brushing }\end{array}$ & $\begin{array}{l}\text { Mefakia (traditional } \\
\text { stick) } \\
\text { Toothbrush with paste } \\
\text { Charcoal }\end{array}$ & $\begin{array}{l}131 \\
134 \\
4\end{array}$ & $\begin{array}{l}48.7 \\
49.8 \\
1.5\end{array}$ \\
\hline
\end{tabular}

\section{Prevalence of Dental Caries}

The prevalence of dental caries was 23.64\% (95\% CI: $19.30,28.00)$ and the lower 1 st molar was the commonly affected (56.7\%) tooth. Females had a higher prevalence of dental caries than Males (30.6\% vs $17.0 \%)$ and the

Table 3 Carbohydrate Intake, Smoking and Presence of Other Chronic Medical Illness Among the Study Participants

\begin{tabular}{|c|c|c|c|}
\hline & & Frequency & Percentage \\
\hline $\begin{array}{l}\text { Carbohydrate } \\
\text { consumption }\end{array}$ & $\begin{array}{l}\text { Yes } \\
\text { No }\end{array}$ & $\begin{array}{l}273 \\
95\end{array}$ & $\begin{array}{l}74.2 \\
25.8\end{array}$ \\
\hline $\begin{array}{l}\text { Type of carbohydrate } \\
\text { taken }\end{array}$ & $\begin{array}{l}\text { Candy } \\
\text { Soft } \\
\text { beverages } \\
\text { Chewing } \\
\text { gum } \\
\text { Tea } \\
\text { Others }\end{array}$ & $\begin{array}{l}24 \\
78 \\
33 \\
112 \\
26\end{array}$ & $\begin{array}{l}8.8 \\
28.6 \\
12.1 \\
41.0 \\
9.5\end{array}$ \\
\hline Smoking habits & $\begin{array}{l}\text { Yes } \\
\text { No }\end{array}$ & $\begin{array}{l}23 \\
337\end{array}$ & $\begin{array}{l}8.4 \\
91.6\end{array}$ \\
\hline Frequency of smoking & $\begin{array}{l}\text { Sometimes } \\
\text { Once/day } \\
3 \text { times/day } \\
>3 \text { times/day }\end{array}$ & $\begin{array}{l}12 \\
4 \\
4 \\
3\end{array}$ & $\begin{array}{l}52.2 \\
17.4 \\
17.4 \\
13.0\end{array}$ \\
\hline Diabetic mellitus patient & $\begin{array}{l}\text { Yes } \\
\text { No }\end{array}$ & $\begin{array}{l}22 \\
346\end{array}$ & $\begin{array}{l}5.9 \\
94.1\end{array}$ \\
\hline History of hypertension & $\begin{array}{l}\text { Yes } \\
\text { No }\end{array}$ & $\begin{array}{l}11 \\
357\end{array}$ & $\begin{array}{l}3.0 \\
97.0\end{array}$ \\
\hline
\end{tabular}

prevalence was higher in rural residents than the urban residents $(30.8 \%$ vs $21.7 \%, \mathrm{p}=0.095)$. The prevalence was high in a patient with halitosis $(42.26 \%), \mathrm{DM}(68.2 \%)$, and malocclusion (40.0\%) (Table 4).

\section{Decayed, Missed and Filled Tooth (DMFT)}

The mean DMFT of the study participants was $1.095 \pm 0.24$ (SD). The decayed part accounts for $70.59 \%$ of the DMFT value and it's lonely contributes 0.78 of the mean DMFT. Filled tooth accounts only $2.17 \%$ of the mean DMFT. The DMFT score was higher in females $(0.625)$, urban residents (0.85), and monthly income of $\leq 2500$ Ethiopian birr (0.86) The mean dmft was 0.13 (Table 5).

\section{Logistic Regression Analysis}

The factors which had a significant association in the bivariate analysis entered into the multivariable logistic regression model as independent variables for the outcome of dental caries.

The analysis found a significant association between dental caries and gender $(\mathrm{AOR}=2.15$ (1.31 3.52), $\mathrm{P}=0.002)$, low educational status $(\mathrm{AOR}=1.81 \quad(1.05,3.1), \mathrm{P}=0.036)$, monthly income of $<2500$ Ethiopian birr (AOR=3.05 (1.54, $6.02), \mathrm{P}=0.000)$, poor tooth brushing habit $(\mathrm{AOR}=2.44(95 \%$ CI: $1.46,4.07, \mathrm{P}=0.004)$ presence of self-perceived halitosis $(\mathrm{AOR}=10.98(5.68,21.24), \mathrm{P}=0.000)$ and a patient on diabetes mellitus $(\mathrm{DM})(\mathrm{AOR}=8.15(3.2,20.75), \mathrm{P}=<0.0001)$. A patient with a known hypertension history was 2.79 times at risk of developing dental caries, however, the association was not significant $(\mathrm{P}=0.13)$ (see Table 6).

\section{Discussion}

This study attempted to investigate the prevalence of dental caries among patients attended the University of Gondar Comprehensive Hospital dental clinic. The overall prevalence of dental caries was $23.64 \%$ (95\% CI: 19.30, 28.00) which was consistent with a study done in Bahir Dar $(21.8 \%),{ }^{19}$ and Nigeria (25.3\%), ${ }^{20}$ and lower than the study done in Debre tabor Hospital (78.2\%), Gondar (36.3\%), ${ }^{12}$ Addis Ababa (47.4\%), ${ }^{21}$ Axsum (35.4\%), ${ }^{22}$ Finote Selam $(48.5 \%),{ }^{23}$ Sudan $(42 \%),{ }^{24}$ Kosovo $(72.80 \%)^{25}$ and Eritrea $(78 \%){ }^{26}$ This difference might be due to the study population variation and the sociodemographic difference between the countries.

The present study found that dental caries were high in females where females are 2.15 times at risk of developing dental caries $(\mathrm{AOR}=2.15$ (1.31 3.52), $\mathrm{p}=0.002)$ which is consistent with a study done in Turkey ${ }^{27}$ and Canada. ${ }^{28}$ 
Table 4 Prevalence of Dental Caries Based on the Sociodemographic Characteristics and Other Factors

\begin{tabular}{|c|c|c|c|c|}
\hline \multicolumn{2}{|l|}{ Variables } & \multicolumn{3}{|c|}{ Dental Caries } \\
\hline & & \multirow{2}{*}{$\begin{array}{l}\text { Yes No (\%) } \\
32(17.0) \\
55(30.6)\end{array}$} & \multirow{2}{*}{$\begin{array}{l}\text { No No (\%) } \\
156(83.0) \\
125(69.4)\end{array}$} & \multirow{2}{*}{$\begin{array}{l}P \text { value } \\
0.002\end{array}$} \\
\hline Gender & $\begin{array}{l}\text { Male } \\
\text { Female }\end{array}$ & & & \\
\hline Age (years) & $\begin{array}{l}<20 \\
20-29 \\
30-39 \\
40-49 \\
\geq 50\end{array}$ & $\begin{array}{l}16(23.5) \\
32(23.4) \\
27(29.3) \\
4(15.4) \\
8(17.8)\end{array}$ & $\begin{array}{l}52(76.5) \\
105(76.6) \\
65(70.7) \\
22(84.6) \\
37(82.2)\end{array}$ & 0.477 \\
\hline Marital status & $\begin{array}{l}\text { Single } \\
\text { Married } \\
\text { Divorced }\end{array}$ & $\begin{array}{l}36(2 \mid .3) \\
51(27.7) \\
0(0.0)\end{array}$ & $\begin{array}{l}133(78.7) \\
133(72.3) \\
15(100)\end{array}$ & 0.033 \\
\hline Educational status & $\begin{array}{l}\text { Has no formal education } \\
\text { Has formal education }\end{array}$ & $\begin{array}{l}27(32.5) \\
60(21.1)\end{array}$ & $\begin{array}{l}56(67.5) \\
225(78.9)\end{array}$ & 0.061 \\
\hline Occupation & $\begin{array}{l}\text { Farmer } \\
\text { Student } \\
\text { Governmental employee } \\
\text { NGO-employee } \\
\text { Merchant/personal business }\end{array}$ & $\begin{array}{l}12(22.2) \\
32(25.0) \\
8(11.8) \\
0(0) \\
35(32.1)\end{array}$ & $\begin{array}{l}42(77.8) \\
96(75.0) \\
60(88.2) \\
9(100) \\
74(67.9)\end{array}$ & 0.013 \\
\hline Religion & $\begin{array}{l}\text { Orthodox } \\
\text { Muslim } \\
\text { Protestant } \\
\text { Catholic }\end{array}$ & $\begin{array}{l}75(27.7) \\
4(17.4) \\
1(12.5) \\
7(100)\end{array}$ & $\begin{array}{l}255(77.3) \\
19(82.6) \\
7(87.5) \\
0(0)\end{array}$ & 0.098 \\
\hline Residency & $\begin{array}{l}\text { Urban } \\
\text { Rural }\end{array}$ & $\begin{array}{l}63(21.7) \\
24(30.8)\end{array}$ & $\begin{array}{l}227(78.3) \\
54(69.2)\end{array}$ & 0.095 \\
\hline Monthly income & $\begin{array}{l}\leq 25,000 \text { ETB } \\
>2500 \text { ETB }\end{array}$ & $\begin{array}{l}76(28.0) \\
\mathrm{II}(I I .3)\end{array}$ & $\begin{array}{l}195(72.0) \\
86(88.7)\end{array}$ & 0.000 \\
\hline Tooth brushing habits & $\begin{array}{l}\text { Yes } \\
\text { No }\end{array}$ & $\begin{array}{l}5 I(18.9) \\
36(36.4)\end{array}$ & $\begin{array}{l}218(81.1) \\
63(63.6)\end{array}$ & 0.001 \\
\hline Consumption of sugary foods & $\begin{array}{l}\text { Yes } \\
\text { No }\end{array}$ & $\begin{array}{l}71(26.0) \\
16(16.8)\end{array}$ & $\begin{array}{l}202(74.0) \\
79(83.2)\end{array}$ & 0.045 \\
\hline Smoking habits & $\begin{array}{l}\text { Yes } \\
\text { No }\end{array}$ & $\begin{array}{l}8(34.8) \\
63(23.0)\end{array}$ & $\begin{array}{l}15(65.2) \\
211(77.0)\end{array}$ & 0.429 \\
\hline Has Diabetic mellitus & $\begin{array}{l}\text { Yes } \\
\text { No }\end{array}$ & $\begin{array}{l}15(68.2) \\
72(20.8)\end{array}$ & $\begin{array}{l}7(31.8) \\
274(79.2)\end{array}$ & 0.000 \\
\hline Hypertension history & $\begin{array}{l}\text { Yes } \\
\text { No }\end{array}$ & $\begin{array}{l}5(45.5) \\
82(22.9)\end{array}$ & $\begin{array}{l}6(54.5) \\
275(77.1)\end{array}$ & 0.049 \\
\hline Halitosis & $\begin{array}{l}\text { Yes } \\
\text { No }\end{array}$ & $\begin{array}{l}75(43.6) \\
12(6.1)\end{array}$ & $\begin{array}{l}97(54.4) \\
184(93.9)\end{array}$ & 0.000 \\
\hline Malocclusion & $\begin{array}{l}\text { Yes } \\
\text { No }\end{array}$ & $\begin{array}{l}8(40.0) \\
79(22.7))\end{array}$ & $\begin{array}{l}12(60.0) \\
269(77.3)\end{array}$ & 0.072 \\
\hline
\end{tabular}

The high prevalence of dental caries in females might be due to the earlier eruption of a tooth in Girls, frequent Snacking by females, and pregnancy.
The prevalence of dental caries was higher in lowerincome than higher-income participants (AOR $=3.0595 \% \mathrm{CI}$ : $1.54,6.02)$. The difference in the prevalence of dental caries 
Table 5 The Mean DMFT Scores Based on Sex, Residency and Monthly Income of the Participants

\begin{tabular}{|c|c|c|c|c|c|c|c|c|c|}
\hline \multicolumn{2}{|l|}{ Characteristics } & \multicolumn{4}{|c|}{ Permanent Dentition (DMFT) } & \multicolumn{4}{|c|}{ Primary Dentition (dmft) } \\
\hline & & Decayed & Missed & Filled & DMFT & Decayed & Missed & Filled & Dmft \\
\hline \multirow[t]{2}{*}{ Gender } & Male & 126 & 43 & 4 & 0.47 & 25 & 15 & 0 & 0.11 \\
\hline & Female & 162 & 64 & 4 & 0.63 & 0 & 6 & 0 & 0.02 \\
\hline \multirow[t]{2}{*}{ Residency } & Urban & 225 & 81 & 8 & 0.85 & 20 & 14 & 0 & 0.08 \\
\hline & Rural & 63 & 26 & 0 & 0.24 & 5 & 7 & 0 & 0.05 \\
\hline \multirow[t]{3}{*}{ Monthly income } & $\leq 2500 \mathrm{ETB}^{*}$ & 223 & 87 & 8 & 0.86 & 8 & 6 & 0 & 0.04 \\
\hline & $>2500 \mathrm{ETB}^{*}$ & 65 & 20 & 0 & 0.23 & 17 & 15 & 0 & 0.09 \\
\hline & & \multicolumn{3}{|c|}{ Mean DMFT } & $1.09 \pm 0.24$ & \multicolumn{3}{|l|}{ Mean dmft } & .13 \\
\hline
\end{tabular}

Note: *ETB: Ethiopian birr.

Table 6 Multivariate Analyses of Variables Associated with Dental Caries Among Patients Visited the Dental Clinic of the University of Gondar Comprehensive Hospital, Gondar, Ethiopia, 2019

\begin{tabular}{|c|c|c|c|c|c|}
\hline \multicolumn{2}{|l|}{ Variables } & \multicolumn{2}{|c|}{ Dental Caries } & \multirow{3}{*}{$\begin{array}{l}\text { AOR }(95 \% \mathrm{CI}) \\
\mathrm{I} \\
2.15(1.3 \mathrm{I} 3.52)\end{array}$} & \multirow{3}{*}{$\begin{array}{l}\text { P-value } \\
0.002\end{array}$} \\
\hline & & \multirow{2}{*}{$\begin{array}{l}\text { No (\%) } \\
156(82.9) \\
125(69.4)\end{array}$} & \multirow{2}{*}{$\begin{array}{l}\text { Yes (\%) } \\
32(17.1) \\
55(30.6)\end{array}$} & & \\
\hline Gender & $\begin{array}{l}\text { Male } \\
\text { Female }\end{array}$ & & & & \\
\hline Educational status & $\begin{array}{l}\text { No formal education } \\
\text { Has formal education }\end{array}$ & $\begin{array}{l}56(66.7) \\
224(78.9)\end{array}$ & $\begin{array}{l}27(33.3) \\
60(21.1)\end{array}$ & $\begin{array}{l}1.81(1.05,3.1) \\
1\end{array}$ & 0.036 \\
\hline Monthly income & $\begin{array}{l}\leq 2500 \text { ETB } \\
>2500 \text { ETB }\end{array}$ & $\begin{array}{l}195(71.9) \\
86(88.7)\end{array}$ & $\begin{array}{l}76(28.1) \\
11(11.3)\end{array}$ & $\begin{array}{l}3.05(1.54,6.02) \\
1\end{array}$ & 0.000 \\
\hline Tooth brushing habits & $\begin{array}{l}\text { Yes } \\
\text { No }\end{array}$ & $\begin{array}{l}218(81.0) \\
63(63.6)\end{array}$ & $\begin{array}{l}51(19.0) \\
36(36.4)\end{array}$ & 2.44(95\% Cl: I.46, 4.07, & 0.004 \\
\hline Halitosis & $\begin{array}{l}\text { Yes } \\
\text { No }\end{array}$ & $\begin{array}{l}97(57.7) \\
180(93.8)\end{array}$ & $\begin{array}{l}71(42.3) \\
12(6.2)\end{array}$ & $\begin{array}{l}10.98(5.68,21.24) \\
\text { I }\end{array}$ & 0.000 \\
\hline History of DM & $\begin{array}{l}\text { Yes } \\
\text { No }\end{array}$ & $\begin{array}{l}7(31.8) \\
274(79.2)\end{array}$ & $\begin{array}{l}15(68.2) \\
72(20.8)\end{array}$ & $\begin{array}{l}8.15(3.2,20.75) \\
\text { I }\end{array}$ & 0.0001 \\
\hline History of HTN & $\begin{array}{l}\text { Yes } \\
\text { No }\end{array}$ & $\begin{array}{l}6(54.5) \\
275(77.0)\end{array}$ & $\begin{array}{l}5(45.5) \\
82(23)\end{array}$ & $\begin{array}{l}2.79(0.83,9.39) \\
\text { । }\end{array}$ & 0.13 \\
\hline
\end{tabular}

according to the socioeconomic status was observed in a study done in Debre Tabor (AOR $=8.43,95 \%$ CI, 2.6, 27.2). ${ }^{11}$ The high prevalence might be due to the unaffordability of dental services and oral hygiene maintaining materials.

A significantly higher prevalence of dental caries was recorded in participants with poor oral hygiene practice than among a subject who had a habit of tooth brushing $(\mathrm{AOR}=2.44,95 \% \mathrm{CI}: 1.46,4.07)$, which coincides with the results of Finote Selam, ${ }^{23}$ Bahir Dar ${ }^{19}$ and Debre Tabor. ${ }^{11}$ More than 2/3rd (73.1\%) of the study participants had tooth brushing habits. However, only $7.5 \%$ of the participants brushed their teeth twice/day.
This study found a higher prevalence of dental caries among DM patients than non-DM patients, which is similar to a previous study. ${ }^{29}$ A patient with true halitosis was 10.98 times at risk of developing dental caries than a patient without halitosis $(\mathrm{AOR}=10.98$ (5.68, 21.24)). The high prevalence of dental caries might be due to the presence of poor oral hygiene practice and calculus accumulation in patients with self-perceived halitosis.

The mean DMFT of the present study was 1.095 where the decayed part accounts for $70.59 \%$ of the DMFT values and the filled tooth accounts only $2.17 \%$ of the mean DMFT which is relatively similar to a study done in $\mathrm{Jimma}^{30}$ and 
Finote Selam. ${ }^{23}$ However, this result is lower compared with a study done in Eritrea $(\mathrm{DMFT}=2.50( \pm 2.21)),{ }^{26}$ Kenya $(\mathrm{DMFT}=3.9),{ }^{31}$ Uganda $(\mathrm{DMFT}=4.71),{ }^{32}$ and Turkey $(11.44) .^{27}$

\section{Limitations}

This study had some inherent limitations. First, the study focused on patients who attended the dental clinic and we hope they have some sort of knowledge of dentistry. Even if there are a lot of factors that affect the occurrence of dental caries, we only targeted individual-level factors. So, the coming researchers should focus on factors such as; service providers, barriers, and community water fluoridation.

\section{Strengths of the Study}

The first strength was study participants were selected randomly in a systematic way and this reduces the selection bias. The second was the questionnaire was adapted from WHO oral health survey 5 th edition and we make some modifications and the pre-test was done on $10 \%$ of the participants before the actual study.

\section{Conclusion}

The prevalence of dental caries in the study participants was $23.64 \%$, higher in females than males and in diabetic patients. Female gender, poor tooth brushing habits, diabetes mellitus, and halitosis were significant predictors associated with dental caries. To reduce the prevalence of dental caries and minimize its impact on the population oral health education should be given at school level and community-based oral health education programs should be designed.

\section{Abbreviations}

AOR, adjusted odds ratio; DMFT, Decayed, Missed and Filled tooth; OR, Odds Ratio; SD, Standard Deviation; SPSS, Statistical package for social sciences; WHO, World Health Organization.

\section{Data Sharing Statement}

All the related data are available within the manuscript.

\section{Ethics Approval and Consent to Participate}

Ethical clearance was obtained from the University of Gondar IRB office. Before the commencement of the study, a formal letter was given to the department of dentistry. Written consent was obtained from each study participant after explaining the purpose of the study. Parent or legal guardian provided written informed consent (assent) for participants under the age of 18 years. All the participants were informed about the confidentiality of their information. (IRB number: V/P/RCS/05/149/2019).

\section{Acknowledgments}

Our earnest gratitude goes to the University of Gondar Institutional Review Board (IRB) for their review and approval of this research paper. Our sincere gratitude and appreciation is also forwarded to data collectors and participants, without their involvement, it wouldn't have been realized.

\section{Author Contributions}

All authors made substantial contributions to conception and design, acquisition of data, or analysis and interpretation of data; took part in drafting the article or revising it critically for important intellectual content; gave final approval of the version to be published, and agree to be accountable for all aspects of the work.

\section{Funding}

There was no external funding for this research.

\section{Disclosure}

The authors report no conflicts of interest in this work.

\section{References}

1. Ndiaye C. Oral health in the African region: progress and perspectives of the regional strategy. Afr J Oral Health. 2005;2:2-9.

2. Thorpe $\mathrm{S}$. Oral health issues in the African region: current situation and future perspectives. J Dent Educ. 2006;70:8-15.

3. Omitola OG, Arigbede AO. Prevalence of dental caries among adult patients attending a tertiary dental institution in South-South region of Nigeria. P H Med J. 2012;6:52-58.

4. Naito M, Yuasa $\mathrm{H}$, Nomura $\mathrm{Y}$, et al. Oral health status and health-related quality of life: a systematic review. J. Oral Sci. 2006;48(1):1-7. doi:10.2334/josnusd.48.1

5. Santos AP, dos P, Soviero VM. Caries prevalence and risk factors among children aged 0 to 36 months. Pesqui Odontológica Bras. 2002;16(3):203-208. doi:10.1590/S1517-74912002000300004

6. Bagramian RA, Garcia-Godoy F, Volpe AR. The global increase in dental caries. A pending public health crisis. Am J Dent. 2009;22(1):3-8.

7. Kathmandu RY. The burden of restorative dental treatment for children in Third World countries. Int. Dent. J. 2002;52(1):1-9. doi:10.1111/j.1875-595X.2002.tb00589.x

8. Marthaler TM. Changes in dental caries 1953-2003. Caries Res. 2004;38(3):173-181. doi:10.1159/000077752

9. Agbelusi GA, Jeboda SO. Oral health status of 12-year-old Nigerian children. West Afr. J. Med. 2006;25(3):195-198. doi:10.4314/wajm. v25i3.28277

10. Msyamboza KP, Phale E, Namalika JM, et al. Magnitude of dental caries, missing and filled teeth in Malawi: national Oral Health Survey. BMC Oral Health. 2016;16(1):29. doi:10.1186/s12903-0160190-3 
11. Tafere Y, Chanie S, Dessie T, Gedamu H. Assessment of prevalence of dental caries and the associated factors among patients attending dental clinic in Debre Tabor general hospital: a hospital-based cross-sectional study. BMC Oral Health. 2018;18(1):119. doi:10.1186/s12903-018-0581-8

12. Ayele FA, Taye BW, Ayele TA, Gelaye KA. Predictors of dental caries among children 7-14 years old in Northwest Ethiopia: a community based cross-sectional study. BMC Oral Health. 2013;13(1):7. doi:10.1186/1472-6831-13-7

13. Namal N, Can G, Vehid S, Koksal S, Kaypmaz A. Dental Health Status and Risk Factors for Dental Caries in Adults in Istanbul, Turkey. 2008.

14. Petersen PE, Bourgeois D, Ogawa H, Estupinan-Day S, Ndiaye C. The global burden of oral diseases and risks to oral health. Bull. World Health Organ. 2005;83(9):661-669.

15. Okubagzhi GS, Teferra M, Gebre S, et al. Epidemiology of dental caries in a rural highland community, north-western Ethiopia. Ethiop. Med. J. 1987;25(3):127-132.

16. Petersen PE. The global burden of oral diseases and risk to oral health. Bull WHO. 2005;83:641-720.

17. Žemaitienè M, Grigalauskienė R, Vasiliauskienè I, et al. Prevalence and severity of dental caries among 18-year-old Lithuanian adolescents. Medicina. 2016;52(1):54-60. doi:10.1016/j.medici.2016. 01.006

18. Organization, W. H. Oral Health Surveys: Basic Methods. World Health Organization; 2013.

19. Mulu W, Demilie T, Yimer M, Meshesha K, Abera B. Dental caries and associated factors among primary school children in Bahir Dar city: a cross-sectional study. BMC Res Notes. 2014;7(1):949. doi:10.1186/1756-0500-7-949

20. Lawal F, Alade O. Dental caries experience and treatment needs of an adult female population in Nigeria. Afr. Health Sci. 2017;17 (3):905-911. doi:10.4314/ahs.v17i3.34

21. Berhane HY, Worku A. Oral health of young adolescents in Addis Ababa-a community-based study. Open J. Prev. Med. 2014;4 (08):640. doi:10.4236/ojpm.2014.48073
22. Zeru T. Prevalence of dental caries and associated factors among aksum primary school students, Aksum Town, Ethiopia. J Dent Oral Health. 2019;5(1-5):2.

23. Teshome A, Yitayeh A, Gizachew M. Prevalence of dental caries and associated factors among finote selam primary school students aged 12-20 years, finote Selam Town, Ethiopia. OHDM. 2016;12:15-17.

24. Raadal M, ELHASSAN FE, Rasmussen P. The prevalence of caries in groups of children aged 4-5 and 7-8 years in Khartoum, Sudan. Int. J. Paediatr. Dent. 1993;3(1):9-15. doi:10.1111/j.1365-263X.1993. tb00041.x

25. Kamberi B, Koçani F, Begzati A, et al. Prevalence of dental caries in Kosovar adult population. Int J Dent. 2016;2016:1-6. doi:10.1155/ 2016/4290291

26. Andegiorgish AK, Weldemariam BW, Kifle MM, et al. Prevalence of dental caries and associated factors among 12 years old students in Eritrea. BMC Oral Health. 2017;17(1):169. doi:10.1186/s12903-017-0465-3

27. Namal N, Can G, Vehid S, Koksal S, Kaypmaz A. Dental health status and risk factors for dental caries in adults in Istanbul, Turkey. East Mediterr Health J. 2008;14(1):110-118.

28. Lukacs JR, Largaespada LL. Explaining sex differences in dental caries prevalence: saliva, hormones, and "life-history" etiologies. Am. J. Hum. Biol. Off. J. Hum. Biol. Assoc. 2006;18(4):540-555. doi:10.1002/ajhb.20530

29. Malvania EA, Sheth S, Sharma A, et al. Dental caries prevalence among type II diabetic and nondiabetic adults attending a hospital. J. Int. Soc. Prev. Community Dent. 2016;6(9):S232. doi:10.4103/ 2231-0762.197202

30. Kebede B, Kemal T, Abera S. Oral health status of patients with mental disorders in southwest Ethiopia. PLoS One. 2012;7(6): e39142. doi:10.1371/journal.pone.0039142

31. Crouch S, Dzingle J, Tyus J, et al. Oral health status of adults in rural Meru, Kenya. OHDM. 2016;15(1):1-13.

32. Kutesa A, Kasangaki A, Nkamba M, et al. Prevalence and factors associated with dental caries among children and adults in selected districts in Uganda. Afr Health Sci. 2015;15(4):1302-1307. doi:10.4314/ahs.v15i4.33
Clinical, Cosmetic and Investigational Dentistry

\section{Publish your work in this journal}

Clinical, Cosmetic and Investigational Dentistry is an international, peer-reviewed, open access, online journal focusing on the latest clinical and experimental research in dentistry with specific emphasis on cosmetic interventions. Innovative developments in dental materials, techniques and devices that improve outcomes and patient

\section{Dovepress}

satisfaction and preference will be highlighted. The manuscript management system is completely online and includes a very quick and fair peer-review system, which is all easy to use. Visit http://www.dovepress.com/testimonials.php to read real quotes from published authors. 